\title{
Systemic viral disease of the chromide cichlid Etroplus maculatus
}

\author{
R. D. Armstrong, H. W. Ferguson \\ Dept of Pathology, Ontario Veterinary College, University of Guelph, Guelph, Ontario, Canada N1G 2W1
}

ABSTRACT. A disease of orange chromide cichlids causing gill pallor and progressive weakness leading to death was investigated. Histopathological changes included ballooning degeneration of cells in many tissues, and the presence of intranuclear inclusion bodies. Polyhedral viral particles (180 to $200 \mathrm{~nm}$ ) were observed on transmission electron microscopy of infected cells.

There are few reported viral diseases of aquarium fish. The most common, and the only one previously diagnosed in this laboratory, is lymphocystis disease, caused by an iridovirus. A viral disease of cichlids was reported in Ramirez' Dwarf Cichlid Apistogramma ramirezi (Leibovitz \& Riis 1980) and another in the Rio Grande cichlid Cichlasoma cyanoguttatum (Malsberger \& Lautenslager 1980).

The present report describes an outbreak of viral disease in a group of orange chromide cichlid Etroplus maculatus Bloch. Two young adult 'red chromides' (a colour variant of the orange chromide) were submitted alive for necropsy by a tropical fish wholesaler. These fish had been imported from Singapore, and were from a group in a single brackish-water tank, in which individuals were reported to exhibit gill pallor and progressive weakness leading to death.

Externally, the fish were thin and paler than other fish in the tank. They had marked pallor of the gills, but whole-mounts of gills were normal, indicating that the pallor was probably due to anemia rather than hyperplasia of the respiratory epithelium. No ectoparasites were found in skin scrapings. Internally, the visceral organs were pale, although in one specimen there was also marked hyperemia of the serosal vessels on the stomach and intestine. Kidney tissue was cultured on trypticase soy agar (TSA, Difco) and blood agar. No growth was observed on the bacteriological plates after incubation for $4 \mathrm{~d}$ in air at room temperature.

Both fish were fixed in Bouin's fixative, sagittally and transversely sectioned to include all major organs, and then routinely processed for paraffin sections which were stained with hematoxylin and eosin. On light microscopy, the most striking finding was an almost complete replacement of hematopoietic renal interstitial tissue by a heterogeneous population of hypertrophic cells. There was an apparent progression of cellular change from blast-like cells with slight nuclear enlargement compressing a basophilic cytoplasm to ballooned cells with an indistinct nuclear membrane and pale granular cytoplasm containing small refractile eosinophilic bodies (Fig. 1). Large amphophilic angular inclusion bodies filled the nuclei of many of the blastlike cells. These abnormal cells could be found in blood vessels throughout the circulatory system of the fish including those of the gill, spleen, liver, meninges, choroid rete, iris, and ovary, as well as the heart. Large numbers of ballooned cells were observed in the intestinal lamina propria, where in one fish they were associated with focal congestion and hemorrhage.

Following the tentative diagnosis of a viral disease, 24 more fish, many exhibiting clinical signs, were obtained from the same group. Intestine, kidney, and gills were taken from 2 affected fish for ultrastructural examination. The tissues were fixed at $4{ }^{\circ} \mathrm{C}$ in $2.5 \%$ gluteraldehyde in a phosphate buffer (pH 7.4; total osmolality ca $320 \mathrm{mOsm}$ ), and embedded in resin. Thin sections were cut and stained with uranyl acetate and lead citrate. Examination of hypertrophic cells in the intestinal lamina propria and the branchial vascular sinus revealed numerous virions present as large aggregates within many cells (Fig. 2). The polyhedral particles measured 180 to $200 \mathrm{~nm}$ and had a round central core.

Light microscopical and ultrastructural findings confirmed that this outbreak of disease was viral in nature. The size, structure and cytoplasmic assembly of this virion place it in the family Iridoviridae, although 


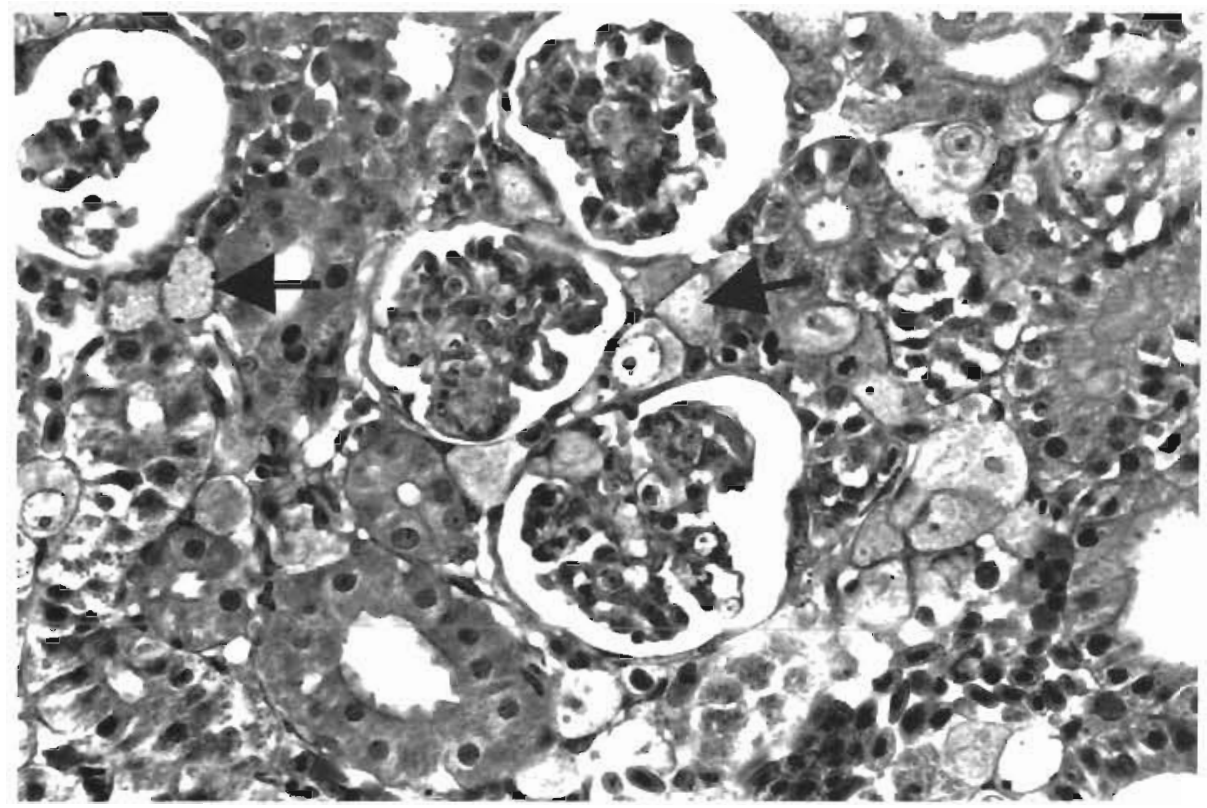

Fig. 1 Etroplus maculatus. Section of posterior kidney with hypertrophy and degeneration of cells in the interstitial tissue (arrows) $H \& E_{;} \times 224$

further classification will depend on successful culture, which we are attempting There was moderate hypertrophy to ballooning of cells in the present case, but the extreme cytomegaly typically associated with lymphocystis did not occur. Moreover, lymphocystis is rarely a systemic disease. The viral disease of ram cichlids descrnbed by Liebovitz \& Riis (1980) had some features resembling the present case, notably progressive ballooning and evacuation of the cytoplasm of affected cells, but the virions described from the

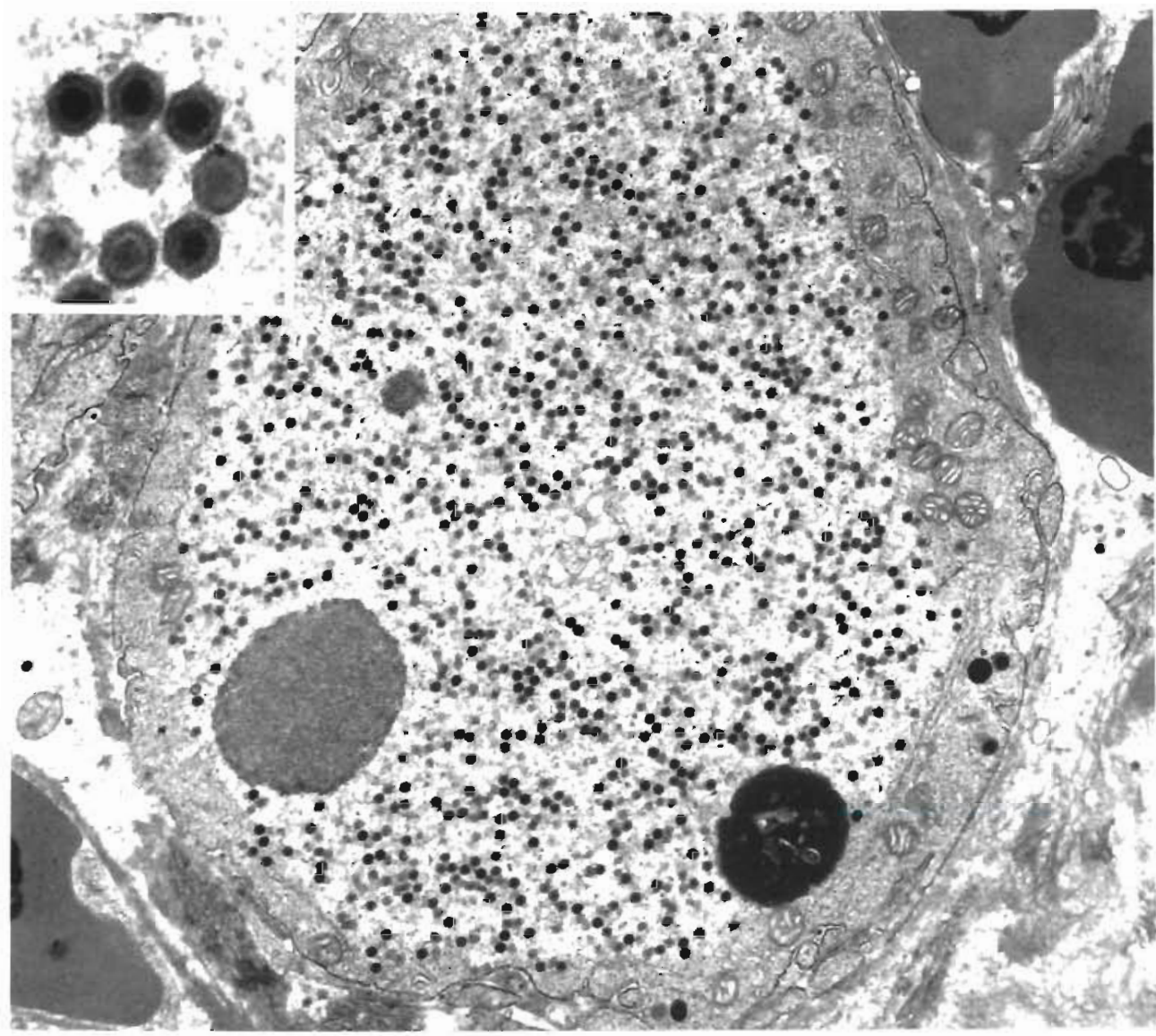

Fig. 2. Etroplus maculatus Polyhedral virions present within the nucleus of an infected cell in the intestinal lamina propria $(\times 7600)$. Inset: Detail of viral particles $(\times 42000)$ 
pathological material were not polyhedral, and were only 110 to $130 \mathrm{~nm}$, compared to the 180 to $200 \mathrm{~nm}$ of this chromide virus.

Langdon \& Humphrey (1987) recently described an iridovirus disease (epizootic hematopoietic necrosis, EHN) from redfin perch Perca fluviatilis L. in Australia. This disease was also viremic with polyhedral virions measuring 150 to $170 \mathrm{~nm}$. However, the histopathological changes reported suggest that EHN is notably more necrotizing than the disease in the chromides. Studies are presently underway to follow the sequential pathology of the disease in the remaining population of infected cichlids. This should permit more rigorous comparisons of the pathology of the chromide disease to other iridoviral diseases of fish.

Responsible Subject Editor: Dr T Evelyn, Nanaimo, Canada
Acknowledgements. The Fish Pathology Laboratory is mainly funded by the Ontario Ministry of Agriculture and Food. We thank Dr Ron Hedrick for helpful suggestions regarding the identity of the virus.

\section{LITERATURE CITED}

Langdon, J. S., Humphrey, J. D. (1987). Epizootic haematopoietic necrosis, a new viral disease in redfin perch, Perca fluviatilis L., in Australia. J. Fish Dis. 10: 289-297

Leibovitz, L., Riis, R. C. (1980). A viral disease of aquarium fish. J. Am. vet.-med. Ass. 177: 414-416

Malsberger, R. G., Lautenslager G. (1980). Fish viruses: rhabdovirus isolated from a species of the family Cichlidae. Fish Health News 9: i-ii

Manuscript first received: May 11989

Revised version accepted: June 30, 1989 